\title{
Penerapan Metode Tam Terhadap Penerimaan Sistem Informasi Produksi Garment
}

\author{
Nanang Hunaifi \\ AMIK BSI Bandung \\ email: nanang.nnu@bsi.ac.id
}

\begin{abstract}
Abstrak
Sistem infromasi produksi garment muncul untuk menggantikan perkerjaan manual menjadi terkomputerisasi supaya dapat mempercepat pekerjaan, penelitian ini bertujuan untuk mengetahui penerimaan karyawan perusahaan tersebut khususnya bagian administrasi produksi selama proses pergantian sistem itu, untuk pemecahan masalah dengan menggunakan metode Technologi Acceptance Model (TAM) yang dirasa cocok untuk menguji permasalahan tersebut. tiga konstruk yaitu persepsi tentang persepsi kemanfaatan (perceived usefulness) kemudahan penggunaan (perceived ease of use), sikap terhadap penggunaan (attitude toward using), untuk menguji tentang penerimaan sistem informasi produksi garment. Penelitian ini mengambil populasi sampel 100 dari 668 karyawan PT. Asia Penta Garment, teknik pengambilan sampel dengan menggunakan random sampling, pengumpulan data menggunakan kuesioner, pengujian menggunakan Analisis Regresi Linier Berganda. Hasilnya terdapat pengaruh yang signifikan antara variabel Perceived Usefulness $\left(X_{1}\right)$ mempengaruhi variabel Attitude Toward Using $(Y)$ dan terdapat pengaruh yang signifikan antara Variabel Perceived Ease Of Use $\left(X_{2}\right)$ mempengaruhi variabel Attitude Toward Using $(Y)$ serta Variabel Perceived Usefulness $\left(\mathrm{X}_{1}\right)$ dan Variabel Perceived Ease Of Use $\left(\mathrm{X}_{2}\right)$ mempengaruh variabel Attitude Toward Using $(\mathrm{Y})$ dikarenakan nilainya sama baik dan mempunyai hubungan yang positif.
\end{abstract}

Kata Kunci: Sistem Informasi Produksi Garment, TAM, Analisis Regresi Linier Berganda.

\begin{abstract}
Garment production information system emerged to replace manual work to be computerized in order to speed up the work, this research aims to know the acceptance of the company's employees, especially the production administration during the change of the system, for troubleshooting by using Technologi Acceptance Model (TAM) to test the problem. three constructs: perception of perceived usefulness (perceived ease of use), attitude toward use, to test the acceptance of garment production information system. This study takes a sample population of 100 of 668 employees of PT. Asia Penta Garment, sampling technique using random sampling, data collection using questionnaire, testing using Multiple Linear Regression Analysis. The result there is a significant influence between Perceived Usefulness (X1) variable influencing Attitude Toward Using $(Y)$ variable and there is significant influence between Variable Perceived Ease Of Use (X2) influence variable Attitude Toward Using (Y) and Variable Perceived Usefulness (X1) and The Perceived Ease Of Use (X2) variable affects the Attitude Toward Using $(Y)$ variable because the value is equally good and has a positive relationship.
\end{abstract}

Keywords: Garment Production Information System, TAM, Multiple Linear Regresi 


\section{Pendahuluan}

Perkembangan era globalisasi sekarang ini ditandai oleh berbagai macam perubahan dalam berbagai aspek kehidupan manusia. Sebagai contoh yang sangat terlihat dan kontras yaitu perkembangan di bidang teknologi yang dari tahun ke tahun juga mengalami perkembangan pesat. Kemajuan teknologi modern khususnya bidang elektronika, membawa kemudahan dalam melaksanakan tugas-tugas kearsipan. Salah satu pengaruh kemajuan teknologi terhadap bidang kearsipan yaitu dengan adanya inovasi baru pada proses pengarsipan yaitu arsip elektronik. Kelebihan utama dari arsip elektronik tentu saja lebih praktis dan memiliki tingkat risiko yang lebih kecil (Laihad, 2013).

Teknologi informasi salah satu bagian dari kebutuhan akan perkembangan zaman yang membantu para penggunanya menjadi lebih mudah serta efisien dalam pemanfaatannya. Dengan adanya teknologi yang semakin berkembang tidak menjadi hambatan bagi para penggunanya untuk menggunakan sistem informasi yang tersedia. Dari sistem informasi yang dirancang dan dibangun sesuai keinginan penggunanya, maka banyak suatu sistem informasi dibuat secara kebutuhan akan pengguna (Fatmasari \& Ariandi, 2014).

Sebuah sistem yang mampu mengintegrasikan dan merangkum data dari laporan bidang produksi tersebut. Sistem informasi eksekutif dapat menjadi alternatif dalam memecahkan permasalahan tersebut karena kemampuannya untuk memberikan informasi bagi para eksekutif secara ringkas, terintegrasi, mudah dipahami, dan dalam berbagai tingkatan rincian. Adapun sistem informasi eksekutif yang akan dihasilkan nantinya memberikan keleluasaan bagi para eksekutif dalam memperoleh informasi terkini sesuai dengan kebutuhan. Sehingga

dengan adanya laporan yang disajikan dalam format tabel dan chart tersebut, dapat mempercepat proses pengambilan keputusan dan analisis resiko (Noviansyah, Abdillah, \& Syafari, 2014).

Penjualan garmen yang juga meliputi penjadwalan produksi, pembelian bahan baku, serta melakukan kerjasama. Penyelenggaraan kerjasama tersebut antara lain dengan pemilik bahan baku, pemilik garmen lain, dan kerjasama dengan beberapa konsumen dengan batas waktu tertentu. Saat ini sistem yang digunakan perusahaan ini masih menggunakan sistem manual. Namun seiring dengan bertambahnya beban proses produksi yang tinggi maka sering terjadi kesalahan dalam pencatatan data, pencarian data yang lama menjadi kendala perusahaan dalam melakukan manajemen produksi dan proses produksinya (Putri, 2014).

Model penerimaan teknologi (Teknology Acceptance Model) merupakan suatu model penerimaan sistem teknologi informasi yang akan digunakan oleh pemakai. Model TRA dapat diterapkan karena keputusan yang dilakukan oleh individu untuk menerima suatu teknologi sistem informasi merupakan tindakan sadar yang dapat dijelaskan dan diprediksi oleh minat perilakunya. TAM menambahkan dua konstruk utama ke dalam model TRA. Dua konstruk utama ini adalah kegunaan persepsian (perceived uselfulnes) dan kemudahaan penggunaan persepsian (perceived ease of use).TAM berargumentasi bahwa penerimaan individu terhadap teknologi informasi ditentukan oleh dua konstruk tersebut. Kegunaan persepsian (perceived usefulness) dan kemudahaan penggunan persepsian (perceived ease of use) keduanya mempunyai pengaruh ke minat perilaku (behavioral intention). Pemakai teknologi akan mempunyai minat menggunakan teknologi (minat perilaku) jika merasa sistem teknologi bermanfaat dan mudah digunakan (Aziz, Lutfi, Musadieq, \& Susilo, 2013).

Sudah banyak penelitian yang dilakukan untuk mencari penyelesaian dengan metode TAM diantaranya. Hasil penelitian oleh (Hamrul, Soedjono, \& Amborowati, 2013) menunjukkan Hasil penelitian menunjukkan bahwa pada metode TAM, berdasarkan hasil uji statistik t menunjukkan bahwa konstruk percieved usefulness yang paling berpengaruh atau lebih kuat dalam menjelaskan kesuksesan penerapan sistem informasi akademik. Hal ini berarti bahwa sistem informasi akademik telah sukses diterapkan sebab memiliki banyak kegunaan dalam membantu pekerjaan staf dan dosen serta membantu proses perkuliahan. Penelitian lain yang 
dilakukan oleh (Nurry \& Tanaamah, 2015) menunjukkan niat untuk menggunakan dipengaruhi langsung oleh kemudahan dan sikap dalam penggunaan aplikasi. Artinya,user cenderung menggunakan aplikasi untuk menyelesaikan pengelolaan keuangan daerah secara praktis dan efisien, dengan demikian dimanfaatkanlah aplikasi oleh pemerintah daerah sebagai penunjang pengolahan keuangan daerah. Penelitian dari (Rizal, 2014) menghasilkan Implikasi dari hubungan kausal antara faktor-faktor yaitu Perceived Easy of Use (PEOU) berpengaruh pada variabel Perceived Usefulness (PU), dapat menjelaskan bahwa dengan adanya apliaksi dapat memudahkan pekerjaan serta meningkatkan produktivitas.

\section{Metode Penelitian}

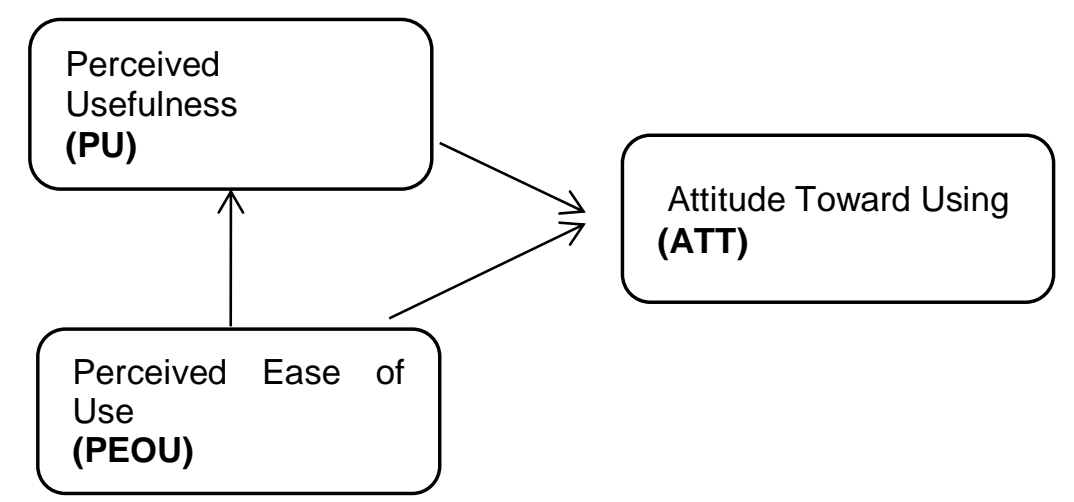

Gambar 1. Hubungan Perceived Ease of Use, Perceived Usefulness, dan Attitude Toward Using

(Jogiyanto, 2008)

Hipotesis yang di ajukan dalam penelitian ini adalah Seberapa besar Perceived Ease of Use, dan Perceived Usefulness pengaruh terhadap Attitude Toward Using.

Metode yang digunakan dalam riset ini adalah Analisis Regensi Linier Berganda dengan menggunakan instrumen kuesioner yang berisikan pernyataan tertutup. Ditetapkan data yang terkumpul berasal dari 100 responden dan menggunakan pendekatan analisis kuantitatif. Hasil dari hubungan variabel diatas digunakan sebagai hipotesis penelitian, selanjutnya verifikasi terhadap hipotesis penelitian digunakan sebagai pembuktian terhadap masing masing hubungan berbagai variable (Darmawan, 2013).

Persamaan regensi linier berganda sebagai berikut (Sugiyono, 2013):

$$
Y=a+b_{1} X_{1}+b_{2} X_{2} \ldots+e
$$

Keterangan:

Y : Variabel Dependen (Nilai Yang diprediksikan)

$\mathrm{X}_{1}$ dan $\mathrm{X}_{2} \quad$ : Variabel Independen

a : Nilai Konstanta

b : Koefisien Regresi (Nilai peningkatan ataupun penurunan)

e : Error atau kesalahan

\section{Hasil dan Pembahasan}

Berdasarkan penelitian yang dilakukan terhadap 100 orang responden yang merupakan karyawan bagian administrasi, didapatkan gambaran umum mengenai profil responden yang diklasifikasikan berdasarkan jenis kelamin, umur, dan masa kerja. 
Tabel 1. Hasil Uji Normalitas

\begin{tabular}{|c|c|c|c|c|}
\hline & & $\begin{array}{l}\text { Perceived } \\
\text { Usefulness }\end{array}$ & $\begin{array}{c}\text { Perceived } \\
\text { Ease Of Use }\end{array}$ & $\begin{array}{l}\text { Attitude } \\
\text { Toward } \\
\text { Using }\end{array}$ \\
\hline \multicolumn{2}{|l|}{$\mathrm{N}$} & 100 & 100 & 100 \\
\hline \multirow{2}{*}{ Normal Parameters ${ }^{\mathrm{a}, \mathrm{b}}$} & Mean & 9,8514 & 16,3808 & 12,5876 \\
\hline & Std. Deviation & 2,11067 & 2,95984 & 2,54951 \\
\hline \multirow{3}{*}{$\begin{array}{l}\text { Most Extreme } \\
\text { Differences }\end{array}$} & Absolute & ,125 & ,097 & ,128 \\
\hline & Positive & ,119 & ,066 & ,097 \\
\hline & Negative &,- 125 &,- 097 &,- 128 \\
\hline \multicolumn{2}{|c|}{ Kolmogorov-Smirnov Z } & 1,250 & ,969 & 1,277 \\
\hline \multicolumn{2}{|c|}{ Asymp. Sig. (2-tailed) } & 088 & ,305 & ,077 \\
\hline
\end{tabular}

Berdasarkan tabel 1 menunjukan bahwa data pada variabel $\mathrm{X}_{1}, \mathrm{X}_{2}$ dan $\mathrm{Y}$, di peroleh pada Asymp.Sig. (2-tailed), yaitu 0,088 perceived usefulness $\left(X_{1}\right), \quad 0,305$ perceived ease of use $\left(\mathrm{X}_{2}\right)$, dan 0,077 attitude toward using ( $\mathrm{Y}$ ) hasil tersebut diatas 0,05. Artinya variabel perceived usefulness, perceived ease of use dan attitude toward using berdistibusi normal dan menggunakan statistik parametrik.

Tabel 2. Uji Autokolerasi

\begin{tabular}{|l|r|r|r|r|r|}
\hline Model & $\mathrm{R}$ & R Square & $\begin{array}{c}\text { Adjusted R } \\
\text { Square }\end{array}$ & $\begin{array}{c}\text { Std. Error of } \\
\text { the Estimate }\end{array}$ & Durbin-Watson \\
\hline 1 & $.665^{\mathrm{a}}$ & .442 & .431 & 1.92358 & 2.131 \\
\hline
\end{tabular}

Berdasarkan hasil pengolahan dengan SPSS 20 diperoleh nilai statistik Durbin-Watson $(\mathrm{D}-\mathrm{W})=2,131$. Jadi hasilnya adalah $1.715<2.131<2.285$ sehingga tidak terjadi autokorelasi. Karna dalam ketentuanya yaitu $\mathrm{du}<\mathrm{d}<(4-\mathrm{du})$ tidak terdapat autokorelasi.

Tabel 3. Hasil Pengujian Asumsi Multikolinieritas Coefficients ${ }^{3}$

\begin{tabular}{|c|c|c|c|c|c|c|c|}
\hline \multirow[t]{2}{*}{ Model } & \multicolumn{2}{|c|}{$\begin{array}{l}\text { Unstandardized } \\
\text { Coefficients }\end{array}$} & \multirow{2}{*}{$\begin{array}{c}\begin{array}{c}\text { Standardiz } \\
\text { ed } \\
\text { Coefficient } \\
\mathrm{s}\end{array} \\
\text { Beta }\end{array}$} & \multirow[t]{2}{*}{$T$} & \multirow[t]{2}{*}{ Sig. } & \multicolumn{2}{|c|}{$\begin{array}{l}\text { Collinearity } \\
\text { Statistics }\end{array}$} \\
\hline & B & Std. Error & & & & $\begin{array}{c}\text { Tolera } \\
\text { nce }\end{array}$ & VIF \\
\hline 1 (Constant) & 2.600 & 1.166 & & 2.230 & .028 & & \\
\hline $\begin{array}{c}\text { perceived ease } \\
\text { of use }\end{array}$ & .486 & .078 & .565 & 6.205 & .000 & .690 & 1.450 \\
\hline $\begin{array}{l}\text { perceived } \\
\text { usefullness }\end{array}$ & .199 & .113 & .160 & 1.763 & .081 & .690 & 1.450 \\
\hline
\end{tabular}

Berdasarkan nilai VIF yang diperoleh seperti terlihat pada tabel 3 diatas menunjukan tidak ada kolerasi yang sangat kuat antara sesama variabel bebas, dimana nilai tolerance $0,690>a=0,05$ dan nilai VIF 1,450 lebih kecil dari 10 maka dapat disimpulkan tidak terdapat multikolinieritas diantara kedua variabel bebas. 


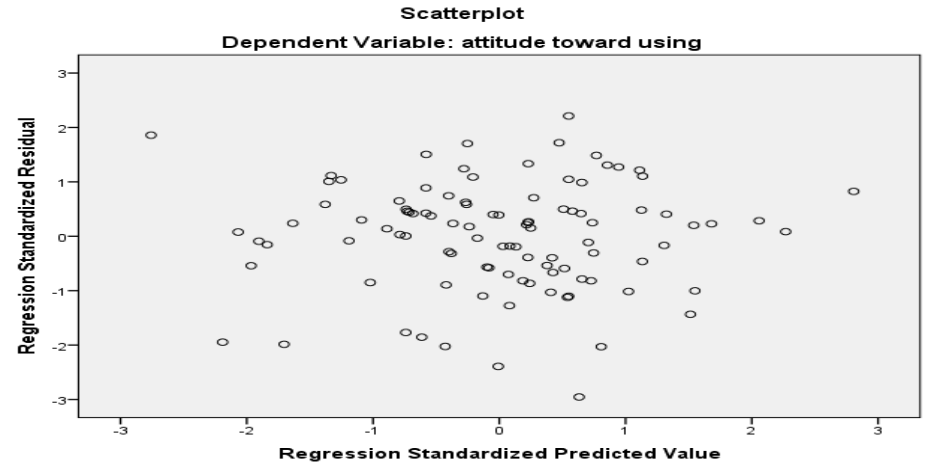

Gambar 2.

Grafik Heteroskedastisitas

Pola gambar Scatterplot di atas menjelaskan bahwa titik-titik data menyebar di atas dan di bawah angka nol, titik-titik data tidak mengumpul hanya diatas atau dibawah saja, penyebaran titik-titik data tidak berpola. Sehingga dapat disimpulkan bahwa tidak terjadi heteroskedastisitas.

\section{Analisis Regresi Linear Berganda}

Analisis regresi linear berganda digunakan untuk mengetahui apakah variabel independen $X_{1} . X_{2}$ secara bersama-sama berpengaruh secara signifikan terhadap variabel dependen Y. Atau untuk mengetahui apakah model regresi dapat digunakan untuk memprediksi variabel dependen atau tidak. Estimasi model regresi linear berganda ini menggunakan software SPSS 20 dan diperoleh hasil output sebagai berikut:

Tabel 4

Hasil Analisis Regresi Linear Berganda

\begin{tabular}{|c|c|c|c|c|c|c|}
\hline \multirow{2}{*}{\multicolumn{2}{|c|}{ Model }} & \multicolumn{2}{|c|}{$\begin{array}{l}\text { Unstandardized } \\
\text { Coefficients }\end{array}$} & \multirow{2}{*}{$\begin{array}{c}\begin{array}{c}\text { Standardize } \\
d \\
\text { Coefficients }\end{array} \\
\text { Beta }\end{array}$} & \multirow[t]{2}{*}{$\mathrm{t}$} & \multirow[t]{2}{*}{ Sig. } \\
\hline & & $B$ & Std. Error & & & \\
\hline \multirow{3}{*}{1} & (Constant) & 2,662 & 1,173 & & 2,269 & -026 \\
\hline & $\begin{array}{l}\text { Perceived } \\
\text { Usefulness }\end{array}$ & 165 & 105 & 136 & 1,576 & ,118 \\
\hline & $\begin{array}{l}\text { Perceived Ease Of } \\
\text { Use }\end{array}$ & ,507 & ,075 & ,588 & 6,799 & ,000 \\
\hline
\end{tabular}

Dari tabel diatas dibentuk persamaan regresi linier sebagai berikut:

$$
\begin{aligned}
& Y=a+b_{1} X_{1}+b_{2} X_{2} \ldots+e \\
& \mathrm{Y}=2,662+0,165 \mathrm{X} 1+0,507 \mathrm{X} 2
\end{aligned}
$$

\section{Dimana:}

a. Konstanta (a) sebesar 2.662 berarti bahwa setiap tidak ada perubahan satu satuan pada semua variabel independent (efisiensi Perceived Usefulness dan Perceived Ease Of Use), maka akan mengalamiperubahan dengan arah yang sama sebesar 2.66 .
$\mathrm{Y}=$ Rasio Variabel Dependent Attitude Toward Using $\mathrm{X} 1=$ Variabel Perceived Usefulness $\mathrm{X} 2=$ Variabel Perceived Ease Of Use.

b. Koefisien regresi (b1) untuk efisiensi Perceived Usefulness sebesar 0,165 dan bertanda positif, berarti bahwa setiap terjadi perubahan satu satuan pada Perceived Usefulness dimana variabel lainnya tetap, maka akan mengalami perubahan dengan arah yang sama sebesar 0,165 . 
c. Koefisien regresi (b2) untuk efisiensi Perceived Ease Of Use sebesar 0,507 danbertanda positif, berarti bahwa setiap terjadi perubahan satu satuan pada Perceived Usefulness dimana variabel lainnya tetap, maka akan mengalami perubahan dengan arah yang sama sebesar 0,507 .

Tabel 5 Koefisien

\begin{tabular}{|c|c|c|c|c|}
\hline Model & $\mathrm{R}$ & $\mathrm{R}$ Square & $\begin{array}{c}\text { Adjusted R } \\
\text { Square }\end{array}$ & $\begin{array}{c}\text { Std. Error of the } \\
\text { Estimate }\end{array}$ \\
\hline 1 &, $665^{\mathrm{a}}$ &, 442 &, 431 & 1,92358 \\
\hline
\end{tabular}

Untuk mengetahui seberapa besar variabel perceived usefulness $\left(\mathrm{X}_{1}\right)$, perceived ease of use $\left(X_{2}\right)$ secara simultan mempengaruhi variabel attitude toward using (Y). Koefisien yang terdapat persamaan diatas dapat diketahui bahwa besarnya $R_{\text {square }}^{2} 0,442$ atau $44,2 \%$. Mempunyai arti

\section{Analisis Pengaruh Variabel Bebas Terhadap Variabel Terikat}

Setelah menilai model secara keseluruhan dan menguji hubungan kausalitas seperti yang dihipotesiskan, tahap selanjutnya adalah pembahasan hasil penelitian sebagai berikut:

a. Analisis pengaruh Perceived Usefulness terhadap Attitude Toward Using dari penerimaan karyawan bagian administrasi terhadap hasil sistem informasi produksi garment. Ternyata Perceived Usefullness itu memiliki hubungan yang positif dengan Attitude Toward Using dengan tingkat hubungan 0,165.

b. Analisis pengaruh Perceived Ease Of use terhadap Attitude Toward Using dari penerimaan karyawan bagian administrasi terhadap hasil sistem informasi produksi garment. Ternyata Perceived Ease Of use itu memiliki hubungan yang positif dengan Attitude Toward Using dengan tingkat hubungan 0,507.

c. Analisis pengaruh Perceived Usefulness dan Perceived Ease Of use terhadap Attitude Toward Using dari penerimaan karyawan bagian administrasi terhadap hasil sistem informasi produksi garment. Berdasarkan penelitian pada kolom $\mathrm{R}$ dan $\mathrm{R}$ square, ternyata Perceived Usefulness dan Perceived Ease Of Use itu memiliki hubungan yang positif dengan Attitude Toward Using dengan tingkat hubungan $\mathrm{R}$ 0,665 , dan $R$ square 0.442 . selain itu nampak juga secara nyata mereka itu saling mempengaruhi dimana Perceived Usefulness dan Perceived Usefullnes mempengaruhi Attitude TowardUsing sebesar $44 \%$. bahwa pengaruh perceived usefulness $\left(X_{1}\right)$ dan perceived ease of use $\left(\mathrm{X}_{2}\right)$ secara bersama-sama terhadap attitude toward using (Y) sebesar $44,2 \%$ dan sisanya $45.8 \%$ adalah pengaruh oleh variabel lain diluar penelitian ini.

\section{Kesimpulan}

Hasil pengujian atas model yang diajukan menunjukkan hasil yang baik. Berdasarkan penelitian yang telah dilakukan mengenai penerimaan karyawan bagian administrasi terhadap hasil sistem informasi produksi garment, maka dapat diambil kesimpulan yaitu Terdapat pengaruh yang signifikan antara Variabel Perceived Usefulness mempengaruhi variabel Attitude Toward Using, Terdapat pengaruh yang signifikan antara Variabel Perceived Ease Of Use mempengaruhi variabel Attitude Toward Using dan Variabel Perceived Usefulness dan Perceived Ease Of Use mempengaruh variabel Attitude Toward Using dikarenakan nilainya sama baik dan mempunyai hubungan yang positif. Berdasarkan hasil penelitian tersebut, Disarankan agar mengadakan sosialisasi tentang sistem informasi produksi garment, penerapan sistem tersebut harusnya juga diberikan pembinaan.

\section{Referensi}

Aziz, Lutfi, A., Musadieq, M. A., \& Susilo, H. (2013). Pengaruh kemudahan Penggunaan Terhadap Kemanfaatan Pada sikap Pengguna E-learning. Jurnal Administrasi Bisnis Vol. 6 No. 2 Malang, - .

Darmawan, D. (2013). Metode Penelitian Kuantitatif. Bandung: PT. Remaja Rosdakarya.

Fatmasari, \& Ariandi, M. (2014). Penerapan Metode Technology Acceptance Model ( TAM ) Terhadap Penerimaan KRS Online ( Studi Kasus : Mahasiswa Ilmu Komputer Universitas Bina Darma Palembang ). 
Jurnal IImia Matrik Vol. 16 No. 2 Agustus 2014, 1-20.

Sugiyono. (2013). Metode Penelitian Kuantitatif, Kualitatif dan Kombinasic(

Hamrul, H., Soedjono, B., \& Amborowati, A. Mixed Methods). Bandung: Alfabeta.

(2013). Analisis Perbandingan Metode TAM dan UTAUT dalam Mengukur Kesuksesan Penerapan Sistem Informasi Akademik ( Studi Kasus Penerapan Sistem Informasi STMIK Dipanegara Makassar ). Seminar Nasional Infromatika 2013 UPN Veteran Yogyakarta, - .

Jogiyanto. (2008). Sistem Informasi Keperilakuan. Yogyakarta: ANDI.

Laihad, R. C. (2013). Pengaruh Perilaku Wajib Pajak Terhadap Penggunaan E-Filing Wajib Pajak di Kota Manado. Jurnal EMBA Vol. 1 No. 3 September 2013 ISSN 2303 - 1174, 44-51.

Noviansyah, F., Abdillah, L. A., \& Syafari, R. (2014). Sistem Informasi Eksekutif Bagian Produksi Pada PT. Perkebunan Nusantara VII ( PERSERO ) Distrik Banyuasin. Seminar Nasional Teknologi Informasi, Komunikasi dan Managemen , - .

Nurry, L. P., \& Tanaamah, A. R. (2015). Evalusai Tingkat Penerimaan dan Penggunaan Aplikasi SIMDA menggunakan Technology Acceptance Model pada Kantor Bupati Kabupaten Maluku Tengah. Seminar Nasional Teknologi Informasi.

Putri, C. S. (2014). Pembuatan Sistem Informasi Produksi dan Sub Kontrak Pada Perusahaan Garmen 'X'. Jurnal Ilmia Mahasiswa Universitas Surabaya Vol. 3 No. 1 , -.

Rizal, A. (2014). Analisis Penerapan Project Management Information System ( PMIS ) Menggunakan Metode Technology Acceptance Model (TAM) studi kasus : PT. INDOSAT, Tbk . Jurnal Telekomunikasi dan Komputer vol. 5 No. 1 ISSN 2085 - 4811. 